\title{
Entrepreneurial experimentation: a key function in systems of innovation
}

\author{
Åsa Lindholm-Dahlstrand • Martin Andersson • \\ Bo Carlsson
}

Accepted: 29 May 2018 / Published online: 3 July 2018

(C) The Author(s) 2018

\begin{abstract}
The literature on innovation systems focuses on the supply side (the creation of technology) rather than on how innovations are converted into economic activity and growth via the market (the demand side, and the interface between supply and demand). One implication of this is that there is a dearth of research on the links between innovation systems and economic growth. The purpose of this paper is to begin to fill this gap in the literature. We articulate the function of entrepreneurial experimentation as an essential mechanism for translating new knowledge into economic activity and growth created in innovation systems. We argue that entrepreneurial experimentation comprises both "technical" and "market" experimentation. Spinoffs and acquisitions are proposed as micro-mechanisms that give rise to system-wide entrepreneurial experimentation. Our framework suggests that entrepreneurial experimentation is central in driving both the supply- and the demand-side dynamics of innovation systems, hence linking both innovation systems and entrepreneurship to economic growth.
\end{abstract}

Å. Lindholm-Dahlstrand

CIRCLE (Centre for Innovation, Research and Competence in the Learning Economy), Lund University, Lund, Sweden

e-mail: asa.lindholm_dahlstrand@circle.lu.se

M. Andersson

Department of Industrial Economics, Blekinge Institute of Technology (BTH), Karlskrona/Research Institute of Industrial Economics (IFN), Stockholm, / CIRCLE, Lund University, Lund,
Keywords Entrepreneurship - Experimentation . Innovation system · New technology-based firms . Scale-up Economic growth

\section{Introduction}

It is commonly accepted that new knowledge is a primary source of economic growth, as suggested in the endogenous growth literature (Lucas 1988; Romer 1986, 1990). However, endogenous growth theory does not specify the mechanisms through which new knowledge is converted into economic activity and growth. Braunerhjelm et al. (2010) have suggested that diffusion of new knowledge via entrepreneurship provides the missing link. Acs et al. (2009) propose that spillovers from $R \& D$ activity in universities and incumbent firms are a key mechanism; R\&D activity endogenously creates entrepreneurial opportunities that are materialized by new firms "outside" universities and incumbents.

Sweden

e-mail: martin.andersson@bth.se

B. Carlsson $(\bowtie)$

Department of Economics, Weatherhead School of Management, Case Western Reserve University, US and CIRCLE, Lund

University, Lund, Sweden

e-mail: bo.carlsson@ case.edu 
Although the creation, diffusion, and utilization of new knowledge is a key focus in innovation systems (Carlsson and Stankiewicz 1991; Cooke 2001; Freeman 1987; Lundvall 1992; Nelson 1993), there is a dearth of research on the links between innovation systems and economic growth. This is largely due to the fact that most of the literature on innovation systems is static and descriptive rather than dynamic and analytical, focusing on the supply side (the creation of technology) rather than on how innovations are converted into economic activity and growth via the market (the demand side, and the interface between supply and demand, see Carlsson 2016) and on how innovation systems evolve over time.

The purpose of this paper is to address this gap in the literature. Entrepreneurial activity is inherently experimental in nature (Kerr et al. 2014). We articulate the function of entrepreneurial experimentation as an essential mechanism for translating new knowledge into economic activity and growth created in innovation systems. To this end, we argue that spinoffs and acquisitions - in addition to de novo firms and intrapreneurship - constitute micro-level mechanisms and processes of industrial dynamics that give rise to system-wide entrepreneurial experimentation that creates, selects, and scales up new technology and innovations. This means that entrepreneurial experimentation is central in driving both the supply- and the demand-side dynamics of innovation systems and is thereby crucial in understanding the link between innovation systems and economic growth. Entrepreneurial activity is a key function in technological innovation systems as originally formulated by Carlsson and Stankiewicz (1991), but its role has been largely ignored in the literature.

The paper is organized as follows. In the next section, we discuss the links between knowledge creation, entrepreneurship, and economic growth. We then review extant perspectives on Systems of Innovation and identify important implications of the differences between them. In the fourth section, we describe the role of entrepreneurial experimentation in systems of innovation. This includes proposing two key mechanisms for entrepreneurial experimentation (in addition to de novo startups). ${ }^{1}$ We propose that spinoffs (both corporate and

\footnotetext{
${ }^{1}$ While de novo startups often represent entrepreneurial experiments, they are by definition exogenous to the innovation system and thus are not considered here.
}

academic) and acquisitions are key for a successful entrepreneurial experimentation and the dynamics of innovation systems. In the final section, we discuss the implications of these suggestions and propositions for innovation and entrepreneurship research and practice.

\section{Knowledge creation, entrepreneurship, and economic growth}

Most new knowledge that generates economic growth is created in universities and existing (often large) firms. According to Carlsson et al. (2009), 60\% of $R \& D$ in the USA is carried out by businesses to develop better production processes and products (the development or D part of R\&D). Twenty percent of U.S. R\&D is applied research, mostly in business firms, while $20 \%$ is basic research (of which $60 \%$ is done in universities). A similar pattern can be found in Sweden where more than $2 / 3$ of R\&D is carried out in businesses (mainly a few large firms), and around $27 \%$ in universities (SCB 2014).

Most new knowledge generated in universities benefits the economy via a better educated labor force, but some new knowledge (probably less than 10\%) is commercialized via licensing to existing firms (the main avenue) or via new start-ups (academic spinoffs). This creates new business opportunities and greater variety. Most of the new knowledge created in large firms results in expansion of existing lines of business (via cost reduction and product improvement), but some of it results in new business lines in existing firms or in the formation of new businesses via corporate spinoffs or via acquisitions or corporate reorganization/recombination. Acquisitions represent a major avenue for diversification and for scaling up newly started businesses. Some new firms (de novo firms) are based on previously existing or traditional (exogenous) knowledge (de novo startups represent a much larger percentage of the number of startups than of the contribution to economic growth).

Thus, most R\&D is carried out in existing business firms and results in incremental innovation (improved products and processes) that expands existing businesses via investment and higher productivity. This is the primary source of economic growth. Our concern in this paper is with new knowledge and technologyradical innovation - that is commercialized through experimentation rather than through expansion of existing lines of business. Some of this new knowledge is created 
in incumbent firms and some in academic institutions. In each time period, this is only a small portion of the knowledge created, but over time, it represents a major source of economic growth. Radical innovation gives rise to new products and eventually new industries that compete with and sometimes replace old ones (creative destruction). Radical innovation pushes out the knowledge frontier and creates new opportunities that transform the economy over time. As innovation systems evolve, incremental innovation in incumbent firms tends to become dominant.

This process works out differently in different domains. To illustrate, it is useful to distinguish between two types of technological regimes (Carlsson 2013). Design-driven regimes are typical in well-developed engineering fields. Mechanical engineering, electrical engineering, design and fabrication of semiconductor devices, and software are examples of technology areas operating predominantly under the design regime. In these industries, the innovation system is mature, and innovation is typically of the incremental type. Technical problems are usually attacked through "analytical design"presupposing a well-articulated design space (set of relevant technologies). The search processes taking place in that space are sequential and iterative rather than parallel. The relatively high efficiency of the development processes reflects the fact that the design space utilized is strongly bounded and the performance requirements well defined and easy to operationalize. Design-oriented innovation processes are demand rather than opportunitydriven. Incumbent firms are the primary drivers. Commercialization takes place when incumbent firms expand existing lines of business and diversify by creating new business lines (intrapreneurship or corporate venturing), when employees leave their employer (corporate spinoff) to found a new technology-based firm based on knowledge and ideas acquired in the existing firm, or when new businesses are formed through re-combination or acquisition of existing businesses.

In contrast, discovery-driven regimes are characteristic of fields with poorly articulated or structured design spaces and loosely defined innovation systems. The limited extent to which functions are clearly identified and mapped on the known structures and processes means that the solutions to problems have to be discovered rather than designed (Stankiewicz 2002). Typical for discovery regimes is that innovation is driven by opportunity rather than demand. Technological advances, particularly radical ones, tend to be triggered by serendipitous discoveries, often through application of existing technologies to new areas. Product performance requirements are hard to fully specify and operationalize early in the process. There is often strong dependence on some form of field trials (experimentation). Examples are biotechnology and applications of semiconductor devices. In the life science industry, innovation is increasingly carried out in new entities, dedicated biotechnology firms, for the purpose of commercializing intellectual property (IP) developed in universities. Once commercialization is attained, such spinoffs are typically acquired by existing pharmaceutical firms for scaling up (production, marketing, and distribution). Commercialization of academic research takes place via start-ups (academic spinoffs) or licensing to existing firms. New (exogenous) ideas may also emerge outside the knowledge creation system and result in the creation of de novo startups. Once new knowledge results in a new business or line of business, selection occurs at many levels in the market, by consumers, venture capitalists and so on. Thus, entrepreneurial experimentation is a vehicle for both variety creation and selection.

The development of driverless cars is an example of radical innovation. New technologies are being developed outside the automobile industry (Tesla) or are introduced into the industry via partnerships between automobile manufacturers and IT firms. Volkswagen's partnership with Nvidia and Aurora (a new Silicon Valley startup), Volvo's partnership with Uber, and Fiat Chrysler's partnership with BMW and Intel are examples here. It is also interesting that Google has set up a new entity, Waymo (a new company within the Alphabet group), to partner with existing car makers (Mercer 2018).

It is also noteworthy that the scaling up of automobile production in Detroit (itself the result of a combination of technologies in previously existing mechanical industries such as the manufacture of carriages and wagons, bicycles, and engines; the initial innovations were new combinations through the assembly of standard parts) took place via the Ford Motor Company, essentially a spinoff from Oldsmobile. Ford imported the idea of the moving assembly line from the meat processing industry (Klepper 2004; Carlsson 2013). After this initial radical innovation, innovation in the automobile industry has been much more incremental.

Our analysis focuses on entrepreneurship as a key process in which new technologies and new knowledge are converted into innovations that drive growth. The 
starting point is Carlsson and Eliasson's (2003) theory of the experimentally organized economy (EOE), which outlines a framework for micro-based endogenous growth (see also Eliasson 1991). A key idea in this framework is that economic growth is a result of experimentation that results in new technologies, followed by selection in dynamic markets and hierarchies, and of the capacity of the economic system to capture winning businesses and innovations, while letting go of losing ones. It thus has a two-pronged focus: (i) creation of variety of new technologies and ideas and (ii) selection and retention of "winning" innovations in the form of commercialization of new technologies. The selection process may be thought of as a kind of sorting or filtering process, in which viable and innovative high-impact businesses and innovations are selected by market forces - for example via acquisition of startups by incumbent firms - and scaled up. Based on the EOE framework, we argue that the central function of entrepreneurial experimentation in innovation systems involves creation as well as selection and scaling-up of innovations. Entrepreneurial experimentation relates both to the "supply-side," in terms of the system's capacity to develop variety of new technologies and business ideas that become subject to selection, as well as to the "demand-side," in terms of effective selection and scaling up of innovations and businesses on the market. ${ }^{2}$

The need for technical experimentation on the supplyside is required because of genuine Knightian uncertainties (Knight 1921) regarding which technologies may be useful and feasible. ${ }^{3}$ A large variety of projects raises the odds of developing and selecting "good" technologies, i.e., it is not known a priori which technologies will turn out to be important innovations (commercialized technologies). Likewise, experimentation is crucial in the

\footnotetext{
${ }^{2}$ Entrepreneurs that develop new firms, business models or technology add variety to the economic system (creation). At the same time, entrepreneurship is also central in the selection process that works on and, to some extent, reduces variety (selection). Acquisition is one form of selection mechanism. Entrepreneurship may also intensify competition and thus contribute to the weeding out of inefficient incumbents. This is e.g. one of the indirect effects of new firm formation discussed by Fritsch and Noseleit (2013).

${ }^{3}$ As an example, Gordon Moore, co-founder of Fairchild semiconductors, has explained that one of the biggest mistakes he made while working at Fairchild was to not recognize the importance and general applicability of integrated circuits. He has stated (Moore and Davis 2001, p27-28): "Most of us working in the laboratory ... did not realize at first that we had barely scratched the surface of a technology that would be so important. It was just another product completed, leaving us looking around for a new device to make, wondering, 'what's next?'” (as cited in Klepper 2015).
}

selection stage. For a given new technology, there are often no established business models or markets, no welldefined areas of implementation, and there is uncertainty about synergies with existing technologies and products (Kemp et al. 1998). No single Schumpeterian entrepreneur (new or established) knows beforehand "what works;" nor can knowledge of business models, market niches, and areas of technology implementation easily be deduced from some set of first principles. Entrepreneurial experimentation is crucial in the innovation process itself ("technical experimentation") as well as in translating innovations into economic activity.

We hold that entrepreneurship at the systems level is fundamentally about experimentation (Kerr et al. 2014; Klepper 2015), and that entrepreneurial experimentation therefore is a key element of the domains of innovation systems and entrepreneurship research. Dynamic innovation systems, which feed innovation and growth, must promote or at least accommodate entrepreneurial experimentation.

Entrepreneurial experimentation may be conceived of as part of the absorptive capacity within the system, consisting of receptivity to new technologies and ideas, as well as the ability to act and experiment on them. Similar to Shane's (2000) argument about the discovery of entrepreneurial opportunities, it is possible that limited technological change generates large economic output because entrepreneurs experiment with different ways to exploit new technology. Conversely, significant technological change might generate limited economic output because of lack of entrepreneurial experimentation. Not only the discovery of opportunity, but also the decision to exploit opportunity, is crucial for entrepreneurial experimentation to take place (Schumpeter 1934). Policy-wise, this perspective naturally entails a focus on institutions and incentive structures that stimulate actors (firms, individuals, organizations) to undertake entrepreneurial experimentation (Carlsson and Eliasson 2003).

This line of argument implies that there is a need to explicate the systems features that lead to and stimulate entrepreneurial experimentation. Contributions by Freytag and Thurik (2007) and Fritsch and Wyrwich (2014) note the relative stability of differences in entrepreneurial activity across countries and regions and suggest that non-economic factors such as entrepreneurial culture and attitudes are important determinants. Marx et al. (2009) focus on enforceability of non- 
compete clauses as an institutional feature that influences labor mobility and hence the diffusion of innovation. Yet, a common critique of the traditional innovation systems literature is that it stresses feedback loops and interdependencies, but is rather vague on where those effects come from, how they are materialized, as well as how they are linked to behaviors and incentives of actors in the system (Braunerhjelm and Henrekson 2016).

Given our definition of the function of entrepreneurial experimentation, our task is then to articulate and specify actors and respective actions involved in the three central processes, i.e., creation, selection, and scaling-up of innovations, within a given institutional setting. We also need to specify at the micro level — in terms of actors and actions - how the three processes link up to and feed each other in interdependent ways; it is such interaction that motivates the systems perspectives.

To this end, we put entrepreneurship and experimentation at center stage and develop our framework by stressing the interaction and symbiosis between new technology-based firms and established businesses and universities. ${ }^{4}$ We identify two examples of critical mechanisms - spinoff and acquisition - that drive entrepreneurial experimentation in the system. Both are examples of mechanisms that are relevant in hightechnology and knowledge-intensive contexts (see, e.g., Norbäck and Persson 2014; Andersson and Xiao 2016; Gans and Stern 2003). They also bear directly on a systems' capacity to (i) create new technology and products (creation), (ii) experiment with regard to their applicability in various market and business contexts (selection), and (iii) scale up the commercial potential by embedding new technology and innovations into global sales networks and value chains (scaling-up).

While the role of spinoffs has been acknowledged in the literature on the evolution of industries and industry dynamics (see, e.g., Klepper 2001, 2002), acquisitions are often neglected in discussions of entrepreneurial activity. Established firms purposefully select pertinent acquisition targets. When targets are technology-based

\footnotetext{
${ }^{4}$ From this perspective our framework touches base with the technological systems literature (Carlsson and Stankiewicz 1991). While much of the innovation systems literature focuses on nations, regions, or sectors as the unit of observation (leaving no room for entrepreneurial activity), the technological innovation systems concept is based on individual firms and technologies and recognizes that it is their interaction that drives the system forward, provided that the institutional arrangements are appropriate.
}

new firms, the incentive for acquisition for the acquiring firm is often to embed the target's technologies, products, or services in existing systems and sales networks, or to strengthen the acquirer's technological or knowledge assets. From the point of view of the founders of new firms, they and their organizations typically lack the human capital and financial resources needed to scale up their innovations and to fully exploit their commercial potential. Such resources therefore have to be acquired from outside, for example by being acquired by an established business. This implies that many entrepreneurs have an incentive to be acquired. For example, Baumol (2002) argues that the different roles of new and established firms may be described as a "David-Goliath symbiosis." The life science industry is a perfect example. New and small firms are more likely to develop radical innovations and technologies but lack resources to scale up. Established firms with global sales networks and resources, such as multinational corporations, can enhance or embed the novelties developed by small entrants into existing products and production processes and bring them to a global scale. Acquisition of innovative entrants is one way in which the complementary roles may be realized, and thus exemplifies one form of interaction between new technology-based firms and established firms that could contribute to system-wide innovativeness and economic growth.

To motivate our case in point, we draw on four main sets of literatures: the innovation systems literature (Carlsson 2006, 2007; Lundvall 1992; Nelson 1993), the literature on the origins of new technologybased firms and university and corporate spinoffs (Andersson and Klepper 2013; Klepper 2015; Lindholm Dahlstrand 1997), the literatures on commercialization strategies of innovative start-ups (Norbäck and Persson 2014; Gans and Stern 2003), and the symbiosis between established and large firms (Andersson and Xiao 2016; Baumol 2002; Lindholm Dahlstrand 1997). Insights from these literatures allow us to articulate what makes the system in the sense that we introduce spinoffs and acquisitions as distinct functions that are directly linked to behaviors and incentives of well-defined actors. We also elucidate how these functions are related to system-wide entrepreneurial experimentation and how they induce feedback effects and interdependencies in systemwide entrepreneurial experimentation capable of generating innovations and economic growth. 


\section{Entrepreneurship and entrepreneurs in systems of innovation}

3.1 A brief overview of the innovation systems literature

"Innovation system" is a concept that has diffused rapidly since its introduction in the middle of the $1980 \mathrm{~s}$ (Lundvall 1988). The concept of "National Systems of Innovation" (NIS) was first used by Freeman (1987) in his work on innovation in Japan. The main theoretical underpinnings were that knowledge is a fundamental resource in the economy, that knowledge is produced and accumulated through an interactive and cumulative process of innovation that is embedded in a national institutional context, and that the context therefore matters for innovation outcomes (Lundvall 1992). The traditional innovation system approach focuses on the components within the systems, i.e., organizations and institutions. Organizations are the players or actors, while institutions are the rules of the game (Breschi and Malerba 1997; Edquist 1997; Lundvall 1992; Malerba 2004; Nelson 1993). This is consistent with the notion of "players" and the "rules of game" addressed by North (1990). The "innovation system" concept can also be understood in a narrow as well as in a broad sense (Lundvall 1992). The narrow approach concentrates on those institutions which deliberately promote the acquisition and dissemination of knowledge. The "broad" approach recognizes that these "narrow" institutions are embedded in a much wider socio-economic system.

Much of this literature insists on the central importance of national systems, but a number of authors have argued that globalization has greatly diminished or even eliminated the importance of the nation state (Freeman 2002). Several alternative concepts have emerged that emphasize the systemic characteristics of innovation but concern other levels than the nation state. Sometimes the focus is on a particular country or region, which then determines the spatial boundaries of the system. For example, the literature on "regional systems of innovation" (RIS) has grown rapidly since the middle of the 1990s (cf., e.g., Cooke 1996; Maskell and Malmberg 1999). Carlsson (2006) shows that the majority of theoretical as well as empirical analyses of innovation systems have a national or regional focus. In other cases, the main dimension of interest is a sector or technology. Usually these different concepts and dimensions reinforce each other and do not need to be in conflict.
In contrast to the NIS and RIS approaches, the literature on technological innovation systems (TIS) takes into account factors that are unique to a knowledge field. In the TIS concept's early development stages, it became clear that although national-level features were significant, diverse technological areas included different settings and dynamics (Carlsson et al. 2009). Carlsson and Stankiewicz (1991) define a technological innovation system as a network of agents interacting in a specific economic/industrial area under a particular institutional infrastructure or set of infrastructures and involved in the generation, diffusion, and utilization of technology. In order to transform knowledge into economic activity, entrepreneurial activity (experimentation) is required. TISs are defined in terms of knowledge/competence flows rather than flows of ordinary goods and services, and focus on a knowledge field or product including an interacting group of components. They are multidimensional and incorporate components that are spatially correlated; regionally, nationally as well as globally. These components are actors (such as firms or universities), the technology (such as artifacts or coded and embodied knowledge), institutions (legal and regulatory aspects, culture, and beliefs) and networks (such as political or learning networks). The structural elements, with exogenous factors such as financial or environmental crises, shape system dynamics.

To gain a better understanding of TIS dynamics, the "functional dynamics" of TIS was developed, building on a scheme of key sub-processes in the larger process of innovation and diffusion (Bergek et al. 2008; Hekkert et al. 2007; Jacobsson and Bergek 2004; Johnson and Jacobsson 2001). The sub-processes (or sub-functions, Markard and Truffer 2008) include (Bergek et al. 2008) the following:

- Knowledge development and diffusion (normally placed at the heart of a TIS)

- Influence on the direction of search (different competing technologies, applications, markets, business models, etc.)

- Entrepreneurial experimentation

- Market formation (actual market development and what drives market formation)

- Legitimation (social acceptance and compliance with relevant institutions. Formed through conscious actions by various organizations and individuals which eventually may help the new TIS to overcome its "liability of newness") 
- Resource mobilization (competence/human capital, financial capital, and complementary assets such as complementary products, services, and network infrastructure)

- Development of positive externalities (pooled labor markets, specialized intermediate goods and service providers, information flows, and knowledge spillovers)

Bergek et al. (2008) argue that a TIS without vibrant experimentation will stagnate. It is only when new technologies are commercialized — selected and scaled upthat economic activity takes place. New knowledge does not automatically result in economic growth.

It should be noted that the word "entrepreneurial" does not refer only to new or small firms, but to the more general Schumpeterian notion of an "entrepreneurial function" (i.e., making new combinations). This function may be filled by any type of actor, including large, established firms diversifying into the new technology (Bergek et al. 2008). But, even if the importance of entrepreneurial experimentation is recognized, there is a limited discussion of the individual.

\subsection{Entrepreneurs and entrepreneurship in innovation systems}

Although the systems of innovation literature is influenced by the Schumpeterian tradition, the entrepreneur has remained rather absent in this literature. ${ }^{5}$ With its focus on structure, it tends to overlook the role of entrepreneurship and individual agency in driving innovation (Ács et al. 2014; Bergek et al. 2008; Braunerhjelm and Henrekson 2016). One exception is the TIS literature as introduced by Carlsson and Stankiewicz (1991). They explicitly recognized that entrepreneurs are necessary and that entrepreneurs help to transform networks of agents into so-called development blocks understood as "synergistic clusters of firms and technologies within an industry or group of industries" (ibid, p. 111). Still, in the bulk of the

\footnotetext{
$\overline{5}$ In fact, despite the common roots in Schumpeter and some interrelated topics such as innovation management and technology-based firms, 'entrepreneurship' and 'innovation' have evolved as two largely separate research fields (Landström et al. 2012). While the innovation systems literature has taken a broad systems perspective, the entrepreneurship literature has not systematically considered the wider, systemlevel constraints and outcomes of entrepreneurial action (Ács et al. 2014).
}

innovation systems literature, in particular NIS, entrepreneurs and entrepreneurship are absent. The NIS literature is rooted in the Schumpeter Mark II tradition, which emphasizes the role of large corporations in R\&D (Freeman and Soete 1997). Schumpeter's earlier ideas (Mark I) of entrepreneurs as agents of creative destruction have not been incorporated into the general framework (Ács et al. 2014).

Qian et al. 2012 argue that the insufficient investigations of entrepreneurs and new firms in the literature of innovation systems call for developing a systems approach to entrepreneurship. In making an effort towards this, they define systems of entrepreneurship as "those economic, social, institutional and all other important factors that interactively influence the creation, discovery and exploitation of entrepreneurial opportunities" (ibid, p.562).

There is an emerging literature focusing on the wider system-level conditions and outcomes of entrepreneurial processes. This literature has mainly followed three paths:

i) Entrepreneurial Ecosystems (e.g., Mason and Brown 2014; Stam 2015) — sees entrepreneurs as the central actors, argues that entrepreneurship, in the form of new high growth firms, is not only a result of the ecosystem, but also that entrepreneurs are central actors who help to build and shape the system and focuses on the role of the context (often local) in stimulating or inhibiting entrepreneurship (Stam 2015). ${ }^{6}$

ii) National Systems of Entrepreneurship (e.g., Ács et al. 2014) — system is defined as" .... the dynamic, institutionally embedded interaction between entrepreneurial attitudes, ability, and aspirations, by individuals, which drives the allocation of resources through the creation and operation of new ventures" (ibid, p.479) The focus is on the individual entrepreneur in the national cultural and institutional context.

iii) Entrepreneurial Propensity of Innovation Systems (Radosevic and Yoruk 2013)—Knowledge

\footnotetext{
${ }^{6}$ The most precise definition of entrepreneurial eco-systems is provided by Stam and Spiegel (2016): "A set of interdependent actors and factors coordinated in such a way that they enable productive entrepreneurship within a particular territory".
} 
intensive entrepreneurship (KIE) ${ }^{7}$ is embedded in IS, which is composed of heterogeneous actors and networks of various types and is shaped by institutions (regulatory systems). The focus is on innovation/technology and the national context, with limited links to entrepreneurship and individuals.

All three paths contribute to the development of a theory of entrepreneurship in innovation systems. Radosevic and Yoruk (2013) base their ideas on the functioning of technological systems, where entrepreneurial experimentation is a key function of the system. However, the individual is not given much consideration, and they argue that entrepreneurial activities and entrepreneurial propensity are caused by structural features of the innovation system; that is, they emphasize macro-level conditions that influence entrepreneurial activities. This rather abstract treatment of entrepreneurs may be criticized on the grounds that it precludes the consideration of the origins and regulators of individual agency (Ács et al. 2014). However, Van de Ven (1993) argues that the study of entrepreneurship is deficient if it focuses exclusively on the characteristics and behaviors of individual entrepreneurs, on the one hand, and if it treats the social, economic, and political infrastructure for entrepreneurship as exogenous on the other hand.

Ács et al. (2014) maintain that any definition of National Systems of Entrepreneurship should recognize that entrepreneurship is fundamentally individual-level behavior; which mobilizes resources for opportunity pursuit through the creation of new firms; which is driven by complex population-level interactions between attitudes, aspirations, and ability, which is embedded within a multifaceted economic, social, and institutional context, and which drives economic productivity through the allocation of resources to efficient uses. However, in their empirical analysis they try to measure and compare National Systems of Entrepreneurship as a dynamic interaction between entrepreneurial attitudes, ability, and aspirations; within their institutional contexts, thus, largely ignoring processes of, for example, knowledge creation and technical experimentation in the system. In a sense, they go directly from the individual to the macro level and do not elucidate the

\footnotetext{
${ }^{7}$ Knowledge intensive entrepreneurship (see Malerba 2010) refers to entrepreneurial activity in new ventures that use, absorb, and generate new knowledge and introduce new products and processes into the economy.
}

processes of industrial dynamics that connect individual entrepreneurial efforts to innovation and economic growth.

Our reading of the current literature aiming to bring entrepreneurship and entrepreneurs into the innovation systems literature leads us to conclude that it still does not articulate the role of entrepreneurs and entrepreneurship. The role of entrepreneurship or entrepreneurial experimentation in fostering creation, selection, and scaling up of new technologies and innovations, i.e., the functions that we deem central in an innovation system capable of generating innovations and economic growth, is neither acknowledged nor conceptually developed. While the idea that entrepreneurship is fundamentally about experimentation is not new (see e.g. Kerr et al. 2014; Klepper 2015; Stern 2005), there are few papers that, based on explicit micro-level mechanisms and processes of industrial dynamics, articulate how the behavior of entrepreneurs and entrepreneurship give rise to system-wide entrepreneurial experimentation that creates, selects, and scales up new technology and innovations. ${ }^{8}$ It is this gap in the literature that we aim to address.

\section{Entrepreneurial experimentation in systems of innovation}

\subsection{The need for entrepreneurial experimentation}

There are several challenges associated with commercialization of new ideas, products, and technologies. First, the actual distribution of returns in such ventures has a low median value but very high variance (Hall and Woodward 2010; Scherer and Harhoff 2000). Most new ventures and innovations fail badly, but some turn out to be highly successful. Second, even for professional investors or managers making resource allocation decisions, it is impossible to know in advance which ideas will work (Kerr et al. 2014). There is genuine Knightian uncertainty (Knight 1921).

Entrepreneurial experimentation is a system-wide function that ensures creation, selection, and scaling up (commercial exploitation) of new technologies and innovations. Individuals, organizations, and institutions interact in the exploration, creation, discovery, and

\footnotetext{
${ }^{8}$ For instance, Klepper (2015) focuses on the role of spinoff processes in the development of US high-tech industries, but does not discuss acquisitions and scale-up processes. Kerr et al. (2014) conceptualize entrepreneurship as experimentation and focus on the barriers that investors and firms face in the process of experimentation.
} 
exploitation of opportunities and new ideas. A key issue is that the system is effective in fulfilling all three activities, rather than separate individuals (researchers, entrepreneurs), organizations (research institutes, universities, small and large firms), and institutions (intellectual property rights, incentive structures in the form of, e.g., taxes and regulations, culture) being excellent in fulfilling only one or a few of the activities.

In addition to organizations and institutions that have been stressed in the literature on innovation systems, individuals (e.g., inventors and entrepreneurs) - or individual agency - are of course central. However, this does not necessarily mean that it is individual entrepreneurs who create entrepreneurial opportunities. Instead, the creation of opportunities through technical experimentation (Lynn et al. 1996) is an important and indispensable part. Even if the creation of entrepreneurial opportunities is often not considered as part of the entrepreneurial process (e.g., Audretsch 1995; Shane 2003), it is the basis for entrepreneurial experimentation and the exploitation of opportunities in the system. Entrepreneurial experimentation is not only about whether opportunities exist, but in particular what is done about them and by whom (Ács et al. 2014; Shane 2003; Shane and Venkataraman 2000).

An individual entrepreneur might very well experiment with and exploit knowledge, technology, or ideas created by someone else in the system. In an illustrative case study of one patented MIT-invention, Shane (2000) reports how this invention is licensed to eight different entrepreneurs, all experimenting with different types of market applications. Licensing and selling patents is one way of exploiting ideas commercially. However, the commercial exploitation and experimentation is not necessarily performed by the original inventor.

Technical experimentation is an important and indispensable part of the innovation process, even if it is not always the entrepreneur who creates the opportunities in the first place. Both exploration and exploitation of opportunities are essential for the functioning of the system. A system without exploration and creation of opportunities will form a poor basis for development and economic growth. Likewise, a system without commercial exploitation will not nearly live up to its full potential. Entrepreneurial experimentation is a key function for development of the system. Without experimentation the system will stagnate.

Entrepreneurship that feeds creation as well as selection requires an "infrastructure" for entrepreneurship which includes the development of resource endowments for knowledge, technology, financing mechanisms, and competent labor, as well as an institutional governance structure that legitimizes and incentivizes entrepreneurship and individual action (Van de Ven 1993). An important dimension of an innovation system thus concerns its capacity to provide an efficient infrastructure for entrepreneurship that stimulates entrepreneurial experimentation in the system.

4.2 Entrepreneurial experimentation through interaction between established firms, universities, and new technology-based firms

In what follows, we outline how an infrastructure of established innovative firms and universities - understood as sources of new knowledge, technologies, and ideasmay interact with entrepreneurs who experiment with commercial applications by founding new technologybased firms and stimulate the development of systemwide entrepreneurial experimentation that feeds innovation and growth. This provides an example of micro-level mechanisms and processes of industrial dynamics that, through behaviors of entrepreneurs and entrepreneurship, give rise to system-wide entrepreneurial experimentation.

\subsubsection{From established organizations to new technology and radical innovations - spinoffs}

Entrepreneurial experimentation is most often exemplified by new technology-based and innovative firms bringing novelties in the form of a technology, product, or service to the market. While incumbents often seek to maximize the returns from known technology, rather than devote resources to entrepreneurial experimentation with an uncertain payoff, new entrants instead compete against established players by doing something different. Pioneering a technological innovation is the essence of doing something different: inventing around barriers to entry is a classic strategy by which new firms enter established markets (Hill and Rothaermel 2003). New entrants are unlikely to be able to circumvent the entry barriers that protect incumbents by pursuing incremental innovations, particularly given the capital resources that incumbents can devote to such innovations. Thus, as suggested by Hill and Rothaermel (2003), these different incentives will lead incumbents to drive forward with incremental innovations, whereas entrepreneurial new entrants will pioneer radical innovations.

Decades of research on entrepreneurship and industry dynamics still show that new companies are a 
heterogeneous group, with different survival and employment growth. Only a limited fraction of new firms qualify as innovation-driven Schumpeterian entrepreneurship (see, e.g. Mata et al. 1995). Ex ante, there is of course substantial uncertainty as to the commercial potential of a radical technological innovation. Many seemingly promising innovations fail the test of market acceptance. It is not uncommon that a swarm of new technologies compete with each other as potential replacements for an established technology, with only one or two finally succeeding. A majority of new businesses survive only a short period and among the companies that survive, only a few grow in terms of employment.

At the same time, research shows that the positive effects of entrepreneurship in an economy are largely attributable to the companies that survive for a long time, even if they are relatively few in number (Fritsch and Noseleit 2013; Lindholm Dahlstrand and Billström 2014). Even if the majority of new entrants fail, new technologies often induce significant entry, and it only takes a handful of the "entrepreneurial experiments" to be successful for a discontinuity to materialize (Utterback 1996). For vibrant entrepreneurial experimentation, it is essential that a large number of new (technology-based) ventures are created. Also since new firms entering a market often encompass features that contribute to radical innovations (Henkel et al. 2015), new entrepreneurial firms play a critical role in the entrepreneurial experimentation.

This raises the question: from where do new technology-based and innovative new firms come? Thinking about this issue, it becomes clear that it is hard to discuss Schumpeterian entrepreneurship in the form of new firms without recognizing established businesses and universities. In fact, a key argument in the knowledge spillover theory of entrepreneurship is precisely that entrepreneurial opportunities are created endogenously through R\&D and other knowledge investments, typically in universities and in established firms (Acs et al. 2009). Many of those opportunities are realized and tested on the market (commercial application) in the form of spinoffs from these types of organizations.

As a case in point, consider modern large technologybased firms, such as multinational corporations. They are typically multi-product, are involved in several technologies (or technology areas) and coupled service systems. Furthermore, they tend to have large intangible assets, a high fraction of knowledge workers with specialized advanced skills - i.e., a fine-grained internal division of labor - as well as large investments in R\&D relative to sales (Andersson et al. 2010). ${ }^{9}$ Thereby, they represent environments that are likely to raise the odds that employees and high-level managers are exposed to new knowledge and technologies that have a potential for commercial applications outside the firms' existing product or business areas. It is still common that a large firm does not encourage experimentation outside its technology, product, or business areas. This implies that large R\&D and knowledge-intensive firms have an, often neglected, potential as sources of radical new innovations that are brought to the market through spinoff processes (Andersson et al. 2010, 2012). In other words, large firms can act as incubators for creation that feeds entrepreneurial experimentation. ${ }^{10}$ Entrepreneurship in the form of individual action (by employees), i.e., making a decision to leave a large firm to found a spinoff around new knowledge or technology, is still required to realize the full potential of large firms as sources of radical innovations and novelty.

Spinoffs have also been shown to outperform other types of new firms in several respects. For example, corporate spinoffs have superior post-entry performance in terms of both survival and employment growth (Andersson and Klepper 2013; Eriksson and Kuhn 2006; Lindholm Dahlstrand 1997). This pattern is explained by the fact that spinoffs often inherit capabilities and routines from their parent organization, which gives them an advantage (Agarwal et al. 2004; Klepper 2001). Compared to corporate spinoffs, university spinoffs tend to not show a similar performance premium (Ensley and Hmieleski 2005; Wennberg et al. 2011; Zahra et al. 2007).

However, studies comparing university and corporate spinoffs often neglect the long time-frame that often is needed to convert scientific research into commercially viable products and successful ventures. Lindholm Dahlstrand and Billström (Lindholm Dahlstrand and Billström 2014) show that there are important time-lags before university spinoffs start to grow. One potential explanation of this is that university spinoffs are better

\footnotetext{
${ }^{9}$ Markusen (1995), for example, states that MNCs have four main characteristics: high $R \& D$ relative to sales, a large share of professional and technical workers, products that are new and/or technically complex, and high levels of product differentiation and advertising.

${ }^{10}$ Similar lines of argument are also present in the so-called "anchortenant hypothesis" presented by Agrawal and Cockburn (2003). The idea is here that large R\&D-intensive firms help to develop an "innovation system" because mobility of individuals and other interactions with the external business environment feeds diffusion and spillovers of knowledge from the large firms to other parts of the economic system.
} 
equipped to contribute to disruptive radical innovation and transformative change. Another potential explanation is that new ideas are rejected by incumbents and thus can be exploited only through spinoffs. The role of university spinoffs in transformative change is not a well-researched topic, and there is a need for systematic empirical studies. There are a few empirical indications in the literature, for example, in the German laser (Buenstorf 2007) and wind turbine industries (Bergek and Jacobsson 2003). Buenstorf's (2007) study of entrants seems to suggest that the academic spinoffs played a critical role in the early formative phases, while corporate spinoffs instead became important in the later phases. If these are general patterns or unique characteristics of only some industries is still an unexplored topic. Our reading of the available evidence suggests that corporate and university spinoffs play different but important roles in entrepreneurial experimentation. Even though the majority of technologybased new entrants are corporate spinoffs, university spinoffs appear to play a more important role for longterm renewal and transformative change.

The above line of argument suggests that entrepreneurship may be conceptualized as a function that feeds both creation and selection. New technology-based firms bring new technologies and knowledge to market via commercial applications, and this means that they become subject to selection. The spinoff argument also suggests an important interplay between established organizations - firms as well as universities - and new technology-based firms. Spinoffs constitute a vehicle for spillovers of knowledge and technology from established organizations to the economic system.

\subsubsection{Acquisition and scaling up - complementarities and symbiosis between new innovative entrants and large established firms}

Another type of interplay between large established firms and new innovative entrants occurs in the process of selection and scaling up, in particular, in high-tech and innovative industries. The mechanism we emphasize in this context is acquisitions. Specifically, acquisition is one means by which a "symbiosis" between new technologybased and innovative entrants and large established businesses is realized - it is both a selection mechanism where "good" new firms are selected as acquisition targets as well as a mechanism that may feed scaling up (Andersson and Xiao 2016). To derive this argument, we start by discussing the incentives facing the founders of new firms to be acquired (or to sell) and then go on to discuss the incentives facing the acquiring firms.

From the perspective of start-ups, there are several arguments concerning the incentives that new entrepreneurs have to opt for a commercialization strategy that involves selling the business to an incumbent firm. The main one is that the costs of fully exploiting the commercial potential associated with a new technology or innovation are often high. Gans and Stern (2003) maintain that the commercialization strategy for start-up innovators “... often presents a tradeoff between establishing a novel value chain and competing against established firms versus leveraging an existing value chain and earning returns through the market for ideas" (ibid p. 335). In other words, when the costs of and need for complementary resources to build a novel value chain and expand on international markets are high, commercialization through the market for corporate control is a viable option for start-ups. Norbäck and Persson (2014) build a game theoretic model to analyze entry strategies of entrepreneurs building their business on a new technology. Similar to the argument by Gans and Stern (2003), their model lets entrepreneurs have two options when it comes to commercialization: (i) entering the world market or (ii) selling the business to incumbents. They then show that, under plausible assumptions, the second option is more favorable when incumbents have high market power and when entrants' costs of going global independently are high. These predictions are consistent with the empirical finding that acquisitions of new technologybased firms tend to be more frequent in hightechnology and innovative industries (Andersson and Xiao 2016). In a survey analysis of spinoffs in Sweden, Lindholm (1996) also shows that the ambition to expand or internationalize their businesses was the second most important reason for owners of new technology-based firms to sell.

The literature further points out that a specific hurdle that may steer entrepreneurs towards a strategy to sell their business by being acquired concerns financial resources. Compared to large and established firms, small and young firms' access to capital markets is limited (Himmelberg and Petersen 1994), and difficulties in gaining access to external financing is a main factor preventing small new firms from fully exploiting their commercial potential (Carpenter and Petersen 2002; Colombo and Grilli 2005, 2007). In fact, if venture capital markets are weak and an initial public offering (IPO) unfeasible, then being 
acquired is one of the few available options to secure financing and continue exploiting the technology or product idea that the start-up is based on (Andersson and Xiao 2016). Being acquired by a financially strong incumbent is under these circumstances a way to secure finance (Utterback et al. 1988). Lindholm's (1996) survey analysis also confirms that founders of new technology-based firms cite lack of financial capital as a major motive for selling their businesses.

Turning now to the motives of the acquiring firm, it is of course the case that there are many types of motives for acquisitions. These include (Andersson and Xiao 2016) the following:

- Achieving market power (Stigler 1950)

- Technology sourcing (Granstrand and Sjölander 1990)

- Synergy gains (Hall 1987)

- Lowering transaction costs (Williamson 1975)

- Corporate control (Lichtenberg et al. 1987).

Still, it is clear that, especially in high-technology and innovative industries, acquisitions involving recent technology-based and innovative start-ups tend to be motivated by a strategy to acquire technology and innovations that can be embedded into and/or expand the acquirer's businesses and strengthen its technological capabilities (Granstrand and Sjölander 1990; Desyllas and Hughes 2008). Acquisitions can thus be seen as one form of technology and knowledge transfer process made possible through the market for corporate control.

In fact, it has been suggested in the innovation management literature that, instead of spending valuable resources and managerial talent on growing new radical businesses inside established firms, incumbent firms may instead have as a strategy to facilitate the creation of a network of young, entrepreneurial firms, so-called "feeder firms," that are busy colonizing new niches (Markides 2006). Should such firms turn successful, the established firms can use their complementary resources that enable them either to enter alliances with the new entrants or to acquire the new entrants on favorable terms, thereby enhancing their position (Hill and Rothaermel 2003). Incumbents could also serve as minority investors or as venture capitalists to entrepreneurial firms. For new entrants engaged in radical technological innovation, long gestation periods strain capital resources, increasing the probability that the firms will exhaust their capital resources before they have successfully marketed new products. Then, when the market starts to consolidate, the large incumbents could build a new mass-market business on the platform these feeder firms have provided (Markides 2006). Since the younger firms do not have the resources, power, marketing, and distribution to scale up their creations, this could be "subcontracted" to larger firms or by being acquired.

This type of reasoning is concordant to Williamson's (1975) discussion of a "systems approach" and in particular his proposition of a "systems solution by classical specialization". Even though Williamson introduced what he called the "systems solution" almost 40 years ago, the idea is still quite unexplored in innovation systems contexts. Williamson's argument in brief is that small firms are frequently high performers when it comes to product innovation. Furthermore, small firms often have advantages in the early stages of the innovation process, as well as in less expensive and radical innovations, while large firms have an advantage in the later stages of scaling up innovations. In other words, large scale, or size, is often claimed to be a determinant of malfunction in the earlier and creative stages of the innovation process. ${ }^{11}$ Therefore, as Williamson (1975) proposed, the "systems solution by classical specialization" may be an efficient innovation process. These ideas are conceptually rather close to the argument that there is a "symbiosis" between new and small technologybased and innovative entrants and established large firms that facilitates scaling up, and that acquisition is an important mechanism by which such a symbiosis is realized.

In his hypothesis of a symbiosis between large and small firms, Baumol (2002) argues that small innovative firms have complementary roles in the system-wide innovation process, because they have their respective advantages at different stages of the innovation process. Buenstorf (2016) has explored the complementarity of entrepreneurial entrants and incumbent firms in his study of the role of established firms in the evolution of innovative industries, considering both direct contributions in the form of entry into markets related to their existing ones (related diversification) and indirect contributions via spinoffs and via acquisitions that provide exit options for startups. Small innovative firms often

\footnotetext{
${ }^{11}$ Cohen (2010) reviews the empirical literature on the determination of firms'and industries' innovative activity and performance, focusing in particular on the "neo-Schumpeterian" literature that examines the effects of firm size and market concentration upon innovation.
} 
account for more radical innovations and new technology. Audretsch (1995) shows for example that many radical innovations and technologies are introduced by new and young technology-based firms. In contrast, since large firms can spread costs of innovation over larger production volumes, they have stronger incentives for less radical process innovations (Klepper 1996). However, as argued above, even if new innovative entrants bring more radical innovations to the market, they often lack resources to scale up, refine, and extend them. Larger established firms have complementary capabilities and resources in the form of knowledge, finances as well as an "infrastructure" of global sales networks. They are thus in a better position to enhance or embed the novelties developed by the small entrants into existing products and production processes. Based on their knowledge of the market, their economies of scale and accumulated experiences, they are able to refine the technologies and use their established market channels to exploit innovations on the global market.

The emphasis on global markets is important because it illustrates why founders (or owners) of new technology-based firms may be particularly willing to create networks to multinational corporations, perhaps with the intention to be acquired. Internationalization and outreach to foreign markets is of course important to fully exploit the commercial potential of new technology and innovations. Multinational corporations that have global sales and production platforms may therefore have a greater willingness to pay for an innovation brought to the market than other potential acquirers, provided that the multinational can use already established platforms to leverage the innovation. ${ }^{12}$ Entrepreneurs could therefore purposefully strive to sell their business to multinationals because it is a more rewarding commercialization strategy, compensating their entrepreneurial activities and expertise (Bonardo et al. 2010; Meoli al. 2013). This reinforces the argument of mutually beneficial interaction between typically large global firms and new technology-based firms. To the extent that network formation and contacts between new entrepreneurs and multinationals are facilitated by proximity, it also

\footnotetext{
$\overline{12}$ One could potentially regard existing sales networks and global production systems of MNCs as a kind of platform which can be used to produce, distribute and market many kinds of related products and/or services. Therefore, MNCs may have greater willingness to pay for a new innovation, through acquisition, because they are able to exploit it in large volumes at low costs. The interaction between new firms in biotechnology and classic large established MNCs in pharmaceuticals is a good example.
}

provides tentative arguments why the presence of multinationals in a country, region, or city may be beneficial, not only for commercial exploitation and scaling up of innovations and new technologies brought to the market by new entrants, but also for the potential return that entrepreneurs can get when selling their firm as a commercialization strategy. ${ }^{13}$

The symbiosis often takes the form of partnerships between the firms, or through incumbents acquiring the new technology-intensive firms (Lindholm Dahlstrand 1996). For technology-intensive young companies, collaboration with established large companies may be needed to bring up the volume and get into the major international markets. ${ }^{14}$ This brings us back to Williamson's (1975) suggestion that, because of the small firms' innovation advantages in the early stages, an efficient procedure by which to introduce new products would be to allow the initial stages of the innovation process to be performed by independent innovators and small firms. The successful companies would then be acquired for subsequent development by a large firm. This suggests that acquisitions constitute one way in which the symbiosis can be realized, because it could mean that the acquiring large firm enhances continued technology development and broadens experimentation, or simply provides financial resources to continue working on the innovation. It is in other words a mechanism for scaling up.

\subsubsection{Summary of the argument-Entrepreneurial experimentation through creation, selection, and scaling up}

Figure 1 provides a schematic picture of the process described above. It aims to summarize our arguments suggesting that spinoffs and acquisitions are examples of micro-mechanisms and processes of industrial dynamics that articulate how the behavior of entrepreneurs and entrepreneurship gives rise to system-wide entrepreneurial experimentation that creates, selects, and

\footnotetext{
$\overline{13}$ Such an argument applies in particular to countries with small domestic markets (such as Sweden, Denmark, Switzerland) in industrial contexts where the costs of going abroad independently are high.

${ }^{14}$ In a similar fashion, Henkel et al. (2015) suggest that the existence of a market for technology between entrants and incumbents drives the former to pursue radical innovations. Entrepreneurial experimentation among entrants results in many new firms, which in parallel try to develop innovative solutions to different needs. They also show that in situations where complementary resources of incumbents are necessary for a firm to succeed, the new entrants generally need to be acquired to survive in the long run.
} 
scales up new technology and innovations. It portrays established firms and universities as sources of the creation of new technologies and knowledge and spinoffs (both academic and corporate, in addition to de novo startups) as an entrepreneurial function that connects creation and selection. Spinoffs bring innovations to the market and make them subject to selection. Acquisition bears on both selection and scaling up.

It should be noted that the perspective outlined in Fig. 1 suggests that the classic question in innovation studies, as well as in the Schumpeterian industrial dynamics literature, of whether small or large firms matter the most in innovation is misleading. Instead, the perspective here suggests that they fill complementary roles in innovation and that they operate in interplay. Our arguments are supportive to Haltiwanger et al. (2013) concluding conjecture which they base on an empirical analysis of the respective role of "small versus large versus young" firms in creating jobs in the USA. They state the following:

"It may be, for example, that the volatility and apparent experimentation of young businesses that we have identified is critical for the development of new products and processes that are in turn used by (and perhaps acquired by) the large and mature businesses that account for most economic activity" (ibid p. 361).

In particular, our arguments are meant to illustrate that interaction between large and new firms through technology-related ownership changes, under certain conditions, can be highly conducive to innovativeness and growth.

In line with Baumol (2002), large firms may be sources of new technologies, knowledge, and ideas, but new innovative and technology-based firms are in a better position to bring radical innovations and new technology to the market. Entrepreneurship in the form of spinoffs could be conceived of as a system-wide function that reflects a "systems solution by classical specialization" (Williamson 1975), where new entrants bring radical innovations and new technology to the market.

In the phase of scaling up, the advantage shifts from the new entrants back to large established firms that have complementary resources. Here, acquisitions could be interpreted as a "systems solution by classical specialization" reflecting the fact that the established large firms have pertinent complementary resources and capabilities. Acquisitions may in turn spur further spinoffs, for example, due to disagreements in new organizations (Thompson and Chen 2011; Klepper and Thompson 2010).

Before turning to conclusions, three remarks are in order to put our arguments in context. First, although our focus is not on institutions or policy, we recognize that entrepreneurial experimentation is influenced by formal as well as informal institutions. For example, for spinoffs to happen, there needs to be an institutional framework that provides incentives for individual action and fosters labor market mobility. In fact, one may argue that a crucial feature of an innovation system is to provide incentives for individuals to engage in entrepreneurship and exploit opportunities (Braunerhjelm and Henrekson 2016). ${ }^{15}$

Second, our focus on spinoffs and acquisitions does not mean that genuinely de novo firms are unimportant and that acquisitions are a pre-requisite for scaling up. De novo firms are, by definition, exogenous to the innovation system. We use spinoffs and acquisitions as examples of micro-mechanisms and processes of industrial dynamics to illustrate how entrepreneurship gives rise to system-wide entrepreneurial experimentation that creates, selects, and scales up new technology and innovations. At the same time, both spinoffs and acquisitions are indeed central mechanisms in many high-tech and knowledge-intensive industries where innovations play a key role, such as biotechnology, electronics, and other high-tech engineering industries. Spinoffs have also been shown to play an important role in the evolution of new industries, particularly in early stages where innovation and experimentation are important (US automobile industry, Klepper 2002; laser industry, Klepper and Sleeper 2005; semiconductors, Malone 1985; disk drive industry Agarwal et al. 2004). Bhide (1994) also reports, on examining survey-data, that $71 \%$ of all founders of fast-growing and innovative companies replicated or modified an idea encountered through previous employment. Furthermore, Andersson and

\footnotetext{
$\overline{15}$ The importance of the mechanisms may also be dependent on institutions and the surrounding infrastructure (broadly defined). For example, as argued previously, one reason why founders of new firms may be willing to be acquired (or to sell the firm) is that they lack financial resources to scale up and refine their technology, product or service. Such a lack of financial resources could in turn depend on an institutional context that suppress the development of a wellfunctioning venture capital market (see e.g. Lerner and Tåg 2013). An argument can thus be made that acquisitions may be a less important mechanism for scaling up when institutional contexts are such that venture capital markets function well.
} 


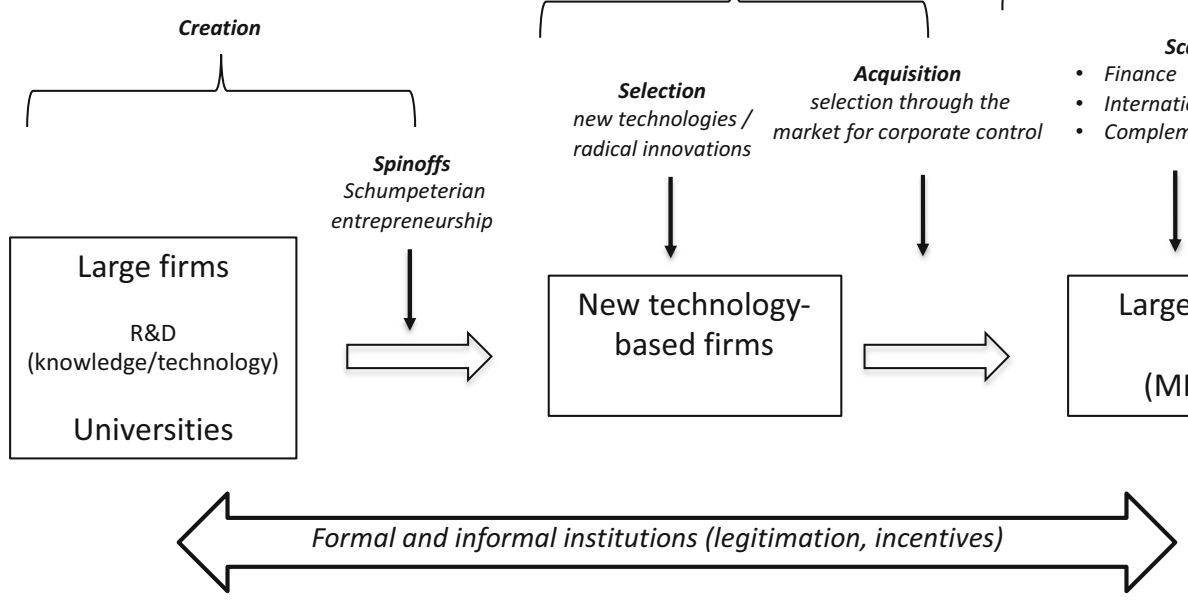

Fig. 1 Creation, selection, and scaling up through spinoffs and acquisitions — an example of system-wide entrepreneurial experimentation

Xiao (2016) study acquisitions of new firms and find evidence that acquisitions of new firms primarily involve new technology-based firms that operate in high-tech and innovative industries characterized by sizeable costs of scaling up, and when incumbents (typically MNEs) have significant market power and complementary assets and capabilities.

Third, our discussion has not addressed the question of system boundaries. This is deliberate since our focus is on articulating the function of entrepreneurial experimentation. However, similar to the literature on technological innovation systems (Carlsson and Stankiewicz 1991), our framework suggests that there are multiple system boundaries. For example, the spinoff process may be location specific in the sense that spinoffs tend to locate close to their parent organizations, and founders are likely to be influenced by the local institutions in the form of attitudes, entrepreneurship culture, and regulations (Carias and Klepper 2010; Andersson and Henrekson 2015; Westlund et al. 2014; Andersson and Larsson 2016; Baltzopoulos et al. 2015). The local scale may also be important when it comes to availability of skilled workers and other types of supply-side resources (Glaeser 2007). Therefore, the relevant boundary may be a high-tech cluster in a region such as Silicon Valley, or a city like Stockholm, London, or Seattle. For selection and scaling up, however, the relevant scale may rather be global and ultimately dependent on the location of major established firms and MNCs, as well as the overall (global) organization of the relevant industry or technology area. The boundary may also be set by the design space - the availability of knowledge and technologies in the relevant cognitive domain. This suggests that the various mechanisms may pertain to different primary boundaries, and the boundaries are likely to change as the organization and location pattern of industries and large established firms evolve and as research changes the content and configuration of the design space.

\section{Summary and concluding remarks}

An institutional environment that facilitates experimentation is central to maintaining a vibrant system of innovation. We argue in this paper that the central function of entrepreneurial experimentation in innovation systems is the creation, selection, and scaling-up of innovations. Entrepreneurial experimentation relates both to the "supply-side," in terms of the system's capacity to develop a variety of new technologies and business ideas that become subject to selection (technical experimentation), as well as to the "demand-side," in terms of the efficiency of selection and scaling up of innovations and businesses on the market (market experimentation). We also argue that both technical and entrepreneurial experimentation are critical for the development of well-functioning systems of innovation. Both forms of experimentation, combined with a willingness to let losing incumbents fail, may in fact be argued to constitute the underlying notion behind Schumpeter's (1942) process of "creative 
destruction." The rate of entrepreneurial experimentation has implications for what types of innovations will occur, who will pursue them and when. As Stern (2005) argued, "a favorable environment for entrepreneurship and a high level of economic experimentation go hand in hand". Although experiments can be conducted in large companies or in the public sector, new technologies and innovative products are often commercialized by entrepreneurs and often cluster at particular times.

Reviewing the extant literature on innovation systems, it is our conclusion that it does not yet articulate the role of entrepreneurs and entrepreneurship in innovation systems. In particular, what is lacking is an analytical framework that, with reference to explicit micro-level mechanisms and processes of industrial dynamics, articulates how the behavior of entrepreneurs and entrepreneurship give rise to system-wide entrepreneurial experimentation that creates, selects, and scales up new technology and innovations.

This paper tries to fill this gap in the literature by focusing on entrepreneurial activity as the mechanism through which innovations are converted into economic activity and growth. In emerging innovation systems, radical innovation is typically carried out by new entitiesuniversity or corporate spinoffs or de novo enterpriseswhereas in mature innovation systems, innovation is more incremental and carried out by incumbent firms through diversification and acquisition. Entrepreneurial experimentation comprises both "technical" and "market" experimentation and is the active ingredient in creating variety within the system. Entrepreneurial activity in the form of new entrants may intensify competition and lead to the weeding out of inefficient incumbents and thus contribute to the selection of viable products. It is also the vehicle for scaling up production; diversifiers from related industries often account for the early successful entrants into new industries. As a result, the nature of entry may change over the life cycle of the innovation system.

In this paper, we conceptualize entrepreneurship analytically in terms of its function in innovation systems rather than as an outcome of an innovation system. That is, from a systems perspective, we claim that entrepreneurship should be looked upon as a function, similar to the way the traditional innovation systems literature treats organizations and institutions when considering functions that determine a system's ability to produce and exploit scientific discoveries and technological innovations that generate economic growth.

To take a step towards the development of a framework that accommodates these requirements, we identified two mechanisms for the entrepreneurial experimentation in the system: spinoffs and acquisitions. Both are micro-based and relate directly to processes of industrial dynamics. We make a strong case that the spinoff mechanism (both corporate and academic) is critical for the creation of high-quality new firms, and that the acquisition mechanism is important for the scaling up of exploitation activities in such firms. Building in particular on Baumol's (2002) conjecture of a symbiosis between new entrants and established firms, we argue that new firms and established incumbents have different advantages and disadvantages in entrepreneurial experimentation, and that they, in interaction with each other through spinoffs and acquisitions, fulfill different roles. Our argument is that a system of innovation where large and new firms interact through spinoffs and technology-related ownership changes, under certain conditions, can be highly conducive to innovativeness and growth. Using the concept of collaborative innovation blocs discussed by Elert and Henrekson (2018), one could argue that large established firms, universities, and new entrepreneurial firms have complementary skills in the innovation system and that their interaction through processes of industrial dynamics are ways in which complementarities are exploited at a system-wide level.

Although our main focus is not on policy, the framework suggests that policy must consider both technical and entrepreneurial experimentation, which means that a careful consideration of the broader institutional framework is necessary, not just the domain of traditional "innovation policy." The experimentation view also suggests that there may be systematic market failures when the costs associated with experimentation are too high or the returns are too uncertain and far into the future. This means that the institutional framework needs to incorporate a long-term perspective. On a general level, an infrastructure of organizations that invest in new knowledge and technology combined with an institutional governance system that promotes interaction between incumbents and new firms and provides incentives of individual action is critical for the functioning of the innovation system. For example, for spinoffs to happen there needs to be an institutional framework that provides incentives for individual action and fosters labor market mobility. In fact, one may argue that a crucial feature of an innovation system is to provide incentives for individuals to engage in entrepreneurship and exploit opportunities (Braunerhjelm and Henrekson 2016). 
Our framework reinforces the argument of Kerr et al. (2014), i.e., that constraints on the ability of entrepreneurs and investors to experiment effectively can shape which industries, organizations, and time periods see the most radical innovations. It also sets the framework for understanding where barriers to experimentation may lead to market failures. When the time horizon for commercialization is extremely uncertain and distant, such as in the case of basic research, institutional regimes may be critical to enable experimentation in areas that are of importance to society but where a process of serial entrepreneurial experimentation by profit-seeking investors is unlikely to provide a set of stepping-stones to the technologies behind disruptive innovation.

Being mainly conceptual, the framework in this paper would need to be complemented and supported by further empirical research, particularly on spinoff and acquisition mechanisms. Important research questions to be considered are the following:

- What are the different roles of entrepreneurial experimentation in transformative change?

- Are the roles different in different sectors and at different points in time?

- If so, why are they different? And to what effect?

Analyzing these questions includes studying the roles that ownership changes (acquisitions and different kinds of spinoffs) in different technological sectors over long time periods. It should also be considered that systems change over time, and that formative phases might be substantially different from phases of expansion or stagnation. This in turn is likely to have important policy implications.

\begin{abstract}
Acknowledgements All authors contributed equally. This research was supported by the Swedish Research Council (VR) grant 2013-994. We acknowledge constructive comments from two anonymous referees and from Torben Schubert, Jing Xiao, Pontus Braunerhjelm, Jonas Gabrielsson, Diamanto Politis as well as comments and suggestions from participants at the $2016 \mathrm{EU}-$ SPRI conference on "Exploring new avenues for innovation and research policies" at CIRCLE, Lund University.
\end{abstract}

Open Access This article is distributed under the terms of the Creative Commons Attribution 4.0 International License (http:// creativecommons.org/licenses/by/4.0/), which permits unrestricted use, distribution, and reproduction in any medium, provided you give appropriate credit to the original author(s) and the source, provide a link to the Creative Commons license, and indicate if changes were made.

\section{References}

Acs, Z. J., Braunerhjelm, P., Audretsch, D. B., \& Carlsson, B. (2009). The knowledge spillover theory of entrepreneurship. Small Business Economics, 32(1), 15-30.

Ács, Z. J., Autio, E., \& Szerb, L. (2014). National systems of entrepreneurship: measurement issues and policy implications. Research Policy, 43(3), 476-494.

Agarwal, R., Raj, E., Franco, A. M., \& Sarkar, M. B. (2004). Knowledge transfer trough inheritance: spinout generation, development and survival. Academy of Management Journal, 47(4), 501-522.

Agrawal, A., \& Cockburn, I. (2003). The anchor-tenant hypothesis - exploring the role of large, local, R\&D-intensive firms in regional innovation systems. International Journal of Industrial Organization, 21, 1227-1253.

Andersson, M., \& Henrekson, M. (2015). Local Competitiveness Fostered through Local Institutions for Entrepreneurship. In D. B. Audretsch, A. N. Link, \& M. Walshok (Eds.), Oxford Handbook of Local Competitiveness. Oxford: Oxford University Press.

Andersson, M., \& Klepper, S. (2013). Characteristics and performance of new firms and spinoffs in Sweden. Industrial and Corporate Change, 22(1), 245-280.

Andersson, M., \& Larsson, J. P. (2016). Local entrepreneurship clusters in cities. Journal of Economic Geography, 16(1), 39-66.

Andersson, M., \& Xiao, J. (2016). Acquisitions of start-ups by incumbent firms - a market selection process of "highquality” entrants? Research Policy, 45(1), 272-290.

Andersson, M., Johansson, B., Karlsson, C., \& Lööf, H. (2010). Multinationals in the knowledge economy - a case study of Astra Zeneca in Sweden. In C. Karlsson \& E. Bohne (Eds.), (2010) Repositioning Europe and America for Growth - the role of governments and private actors in key policy areas. Berlin: LIT Verlag.

Andersson, M., Baltzopoulos, A., \& Lööf, H. (2012). R\&D strategies and entrepreneurial spawning. Research Policy, 41(1), 54-68.

Audretsch, D. B. (1995). Innovation and industry evolution. Cambridge, MA: MIT Press.

Baltzopoulos, A., Braunerhjelm, P., \& Tikoudis, I. (2015). Spinoffs: Why geography matters. Journal of Economic Geography, 16(2), 273-303.

Baumol, W. J. (2002). Entrepreneurship, innovation and growth: the David-goliath symbiosis. Journal of Entrepreneurial Finance: $J E F, 7(2), 1-10$.

Bergek, A., \& Jacobsson, S. (2003). The emergence of a growth industry: a comparative analysis of the German, Dutch and Swedish wind turbine industries. In S. Metcalfe \& U. Cantner (Eds.), Change, transformation and development (pp. 197227). Heidelberg: Physica-Verlag.

Bergek, A., Jacobsson, S., Carlsson, B., Lindmark, S., \& Rickne, A. (2008). Analyzing the functional dynamics of technological innovation systems: a scheme of analysis. Research Policy, 37(3), 407-429.

Bhide, A. (1994). How entrepreneurs craft strategies that work. Harvard Business Review, 72(2), 150-161.

Braunerhjelm, P. and Henrekson, M. (2016). An innovation policy framework: bridging the gap between industrial dynamics and growth. In D. B. Audretsch \& N. Albert (Eds.) Essays in Public Sector Entrepreneurship. New York: Springer. 
Braunerhjelm, P., Acs, Z., Audretsch, D., \& Carlsson, B. (2010). The missing link: Knowledge diffusion and entrepreneurship in endogenous growth. Small Business Economics, 34(2), 105-125.

Breschi, S., \& Malerba, F. (1997). Sectoral innovation systems. In C. Edquist (Ed.), Systems of Innovation: Technologies, Institutions and Organisations. London: Pinter.

Buenstorf, G. (2007). Evolution on the shoulders of giants: entrepreneurship and firm survival in the German laser industry. Review of Industrial Organization, 30(3), 179-202.

Buenstorf, G. (2016). Schumpeterian incumbents and industry evolution. Journal of Evolutionary Economics, 26(4), 823-836.

Carias, C., \& Klepper, S. (2010). Entrepreneurship, the initial labor force, and the location of new firms. International Schumpeter Society Conference, Aalborg.

Carlsson, B. (2006). Internationalization of innovation systems: A survey of the literature. Research Policy, 35(1), 56-67.

Carlsson, B. (2007). Innovation systems: a survey of the literature from a Schumpeterian perspective. In H. Hanusch \& A. Pyka (Eds.), Elgar companion to Neo-Schumpeterian economics (pp. 857-871). Cheltenham: Elgar.

Carlsson, B. (2013). Dissemination mechanisms and innovation regimes in high tech industry clusters in European Commission, Global Innovation Networks: High Level Economic Expert Group 'Innovation for Growth - i4g', Brussels, 77-106.

Carlsson, B. (2016). Industrial dynamics: a review of the literature, 1990-2009. Industry and Innovation, 23(1), 1-61.

Carlsson, B., \& Eliasson, G. (2003). Industrial dynamics and endogenous growth. Industry and Innovation, 10(4), 435455.

Carlsson, B., \& Stankiewicz, R. (1991). On the nature, function, and composition of technological systems. Journal of Evolutionary Economics, 1, 93-118.

Carlsson, B., Acs, Z. J., Audretsch, D. B., \& Braunerhjelm, P. (2009). Knowledge creation, entrepreneurship, and economic growth: a historical review. Industrial and Corporate Change, 18(6), 1193-1229.

Carpenter, R. E., \& Petersen, B. C. (2002). Capital market imperfections, high-tech investment, and new equity financing. The Economic Journal, 112(477), F54-F72.

Cohen, W. M. (2010). Fifty years of empirical studies of innovative activity and performance. Handbook of the Economics of Innovation, 1, 129-213 North-Holland.

Colombo, M. G., \& Grilli, L. (2005). Start-up size: the role of external financing. Economics Letters, 88(2), 243-250.

Colombo, M. G., \& Grilli, L. (2007). Funding gaps? Access to bank loans by high-tech start-ups. Small Business Economics, 29(1-2), 25-46.

Cooke, P. (1996). Regional innovation systems: an evolutionary approach. In H. Baraczyk, P. Cooke, \& R. Heidenriech (Eds.). London: London University Press.

Cooke, P. (2001). Regional innovation systems, clusters, and the knowledge economy. Industrial and Corporate Change, 10(4), 945-974.

Desyllas, P., \& Hughes, A. (2008). Sourcing technological knowledge through corporate acquisition: Evidence from an international sample of high technology firms. The Journal of High Technology Management Research, 18(2), 157-172.

Edquist, C. (Ed.). (1997). Systems of innovation: technologies, institutions and organizations. London: Pinter.
Elert, N. \& Henrekson, M. (2018). The collaborative innovation bloc - a new mission for austrian economics, IFN working paper No. 1222. Stockholm: Research Institute of Industrial Economics

Eliasson, G. (1991). Modeling the experimentally organized economy. Journal of Economic Behavior and Organization, 16(1-2), 153-182.

Ensley, M. D., \& Hmieleski, K. A. (2005). A comparative study of new venture top management team composition, dynamics and performance between university-based and independent start-ups. Research Policy, 34(7), 1091-1105.

Eriksson, T., \& Kuhn, J. M. (2006). Firm spin-offs in Denmark 1981-2000: patterns of entry and exit. International Journal of Industrial Organization, 24(5), 1021-1040.

Freeman, C. (1987). Technology Policy and Economic Performance. London: Pinter Publishers.

Freeman, C. (2002). Continental, national and sub-national innovation systems. Research Policy, 31, 191-211.

Freeman, C., and Soete, L. (Eds.) (1997). The economics of industrial innovation. Psychology Press.

Freytag, A., \& Thurik, R. (2007). Entrepreneurship and its determinants in a cross-country setting. Journal of Evolutionary Economics, 17(2), 117-131.

Fritsch, M., \& Noseleit, F. (2013). Start-ups, long-and short-term survivors, and their contribution to employment growth. Journal of Evolutionary Economics, 23(4), 719-733.

Fritsch, M., \& Wyrwich, M. (2014). The long persistence of regional levels of entrepreneurship: Germany, 1925-2005. Regional Studies, 48(6), 955-973.

Gans, J. S., \& Stern, S. (2003). The product market and the market for "ideas": Commercialization strategies for technology entrepreneurs. Research Policy, 32(2), 333-350.

Glaeser, E. L. (2007). Entrepreneurship and the City (No. w13551). National Bureau of Economic Research.

Granstrand, O., \& Sjölander, S. (1990). The acquisition of technology and small firms by large firms. Journal of Economic Behavior and Organization, 13(3), 367-386.

Hall, R. E., \& Woodward, S. E. (2010). The Burden of the Nondiversifiable Risk of Entrepreneurship. American Economic Review, 100(3), 1163-1194.

Haltiwanger, J., Jarmin, R. S., \& Miranda, J. (2013). Who creates jobs? Small versus large versus young. Review of Economics and Statistics, 95(2), 347-361.

Hekkert, M. P., Suurs, R. A. A., Negro, S. O., Smits, R. E. H. M., \& Kuhlmann, S. (2007). Functions of innovation systems: a new approach for analyzing technological change. Technological Forecasting and Social Change, 74, 413-432.

Henkel, J., Rønde, T., \& Wagner, M. (2015). And the winner isAcquired. Entrepreneurship as a contest yielding radical innovations. Research Policy, 44(2), 295-310.

Hill, C. W., \& Rothaermel, F. T. (2003). The performance of incumbent firms in the face of radical technological innovation. Academy of Management Review, 28(2), 257-274.

Himmelberg, C. P., \& Petersen, B. C. (1994). R \& D and internal finance: A panel study of small firms in high-tech industries. The Review of Economics and Statistics, 76, 38-51.

Jacobsson, S., \& Bergek, A. (2004). Transforming the energy sector: the evolution of technological systems in renewable energy technology. Industrial and Corporate Change, 13, 815-849.

Johnson, A., \& Jacobsson, S. (2001). Inducement and blocking mechanisms in the development of a new industry: the case of 
renewable energy technology in Sweden. In R. Coombs, K. Green, V. Walsh, \& A. Richards (Eds.), Technology and the market: demand, users and innovation. Cheltenham: Edward Elgar.

Kemp, R., Schot, J., \& Hoogma, R. (1998). Regime shifts to sustainability through processes of niche formation: the approach of strategic niche management. Technology Analysis and Strategic Management, 10, 175-195.

Kerr, W. R., Nanda, R., \& Rhodes-Kropf, M. (2014). Entrepreneurship as experimentation. Journal of Economic Perspectives, 28(3), 25-48.

Klepper, S. (2001). Employee startups in high-tech industries. Industrial and Corporate Change, 10(3), 639-674.

Klepper, S. (2002). The capabilities of new firms and the evolution of the US automobile industry. Industrial and Corporate Change, 11(4), 645-666.

Klepper, S. (2004). Agglomeration through spinoffs: how Detroit became the capital of the U.S. Automobile Industry. Working paper, Carnegie Mellon University.

Klepper, S. (2015). Experimental capitalism: the nanoeconomics of American high-tech industries. Princeton University Press.

Klepper, S., \& Sleeper, S. (2005). Entry by spinoffs. Management science, 51(8), 1291-1306.

Klepper, S., \& Thompson, P. (2010). Disagreements and intraindustry spinoffs. International Journal of Industrial Organization, 28(5), 526-538.

Knight, F. H. (1921). Risk, uncertainty and Profit. New York: Hart, Schaffner and Marx.

Landström, H., Harirchi, G., \& Åström, F. (2012). Entrepreneurship: exploring the knowledge base. Research Policy, 41(7), 1154-1181.

Lerner, J., \& Tåg, J. (2013). Institutions and venture capital. Industrial and Corporate Change, 22(1), 153-182.

Lichtenberg, F. R., Siegel, D., Jorgenson, D., \& Mansfield, E. (1987). Productivity and changes in ownership of manufacturing plants. Brookings Papers on Economic Activity, 1987(3), 643-683.

Lindholm, A. (1996). An economic system of technology-related acquisitions and spin-offs. University of Cambridge, ESRC Centre for business research.

Lindholm Dahlstrand, A.. (1997). Growth and innovativeness in technology-based spin-off firms. Research Policy, 26, 331-344.

Lindholm Dahlstrand, $\AA$ and Billström, A. (2014). Corporate and university spin-offs: a study of long-term performance, working paper, working paper, paper presented at Entreprenörskapsforum, may 17-18, 2013, Lund, Sweden..

Lucas, R. (1988). On the mechanics of economic development. Journal of Monetary Economics, 22, 3-39.

Lundvall, B-Å. (1988). Innovation as an Interactive Process: From User Producer Interaction to National systems of Innovation. In G. Dosi, C. Freeman, R. Nelson, G. Silverberg, \& L. Soete (Eds.), Technical Change and Economic theory. Pisa, Italy: Laboratory of Economics and Management (LEM), Sant'Anna School of Advanced Studies.

Lundvall, B.-Å. (Ed.). (1992). National systems of innovation: towards $a$ theory of innovation and interactive learning. London: Pinter.

Lynn, G., Morone, J. G., \& Paulson, A. S. (1996). Marketing and discontinuous innovation: the probe and learn process. California Management Review, 38(3).

Malerba, F. (2004). Sectoral systems of innovation: basic concepts. In F. Malerba (Ed.), Sectoral systems of innovation: concepts, issues and analysis of six major sectors in Europe. Cambridge University Press.

Malerba, F. (Ed.). (2010). Knowledge intensive entrepreneurship and innovation systems: evidence from Europe. Routledge.

Malone, M. (1985). The Big Score: The Billion Dollar Story of Silicon Valley. Garden City, NJ: Doubleday.

Markard, J., \& Truffer, B. (2008). Technological innovation systems and the multi-level perspective: towards an integrated framework. Research Policy, 37(4), 596-615.

Markides, C. (2006). Disruptive innovation: in need of better theory. Journal of Product Innovation Management, 23(1), 19-25.

Markusen, J. R. (1995). The boundaries of multinational enterprises and the theory of international trade. Journal of Economic Perspectives, 9(2), 169-189.

Marx, M., Strumsky, D., \& Fleming, L. (2009). Mobility, skills, and the Michigan non-compete experiment. Management Science, 55(6), 875-889.

Maskell, P., \& Malmberg, A. (1999). Localised learning and industrial competitiveness. Cambridge Journal of Economics, 23(2), 167-186.

Mason, C., and Brown, R. (2014). Entrepreneurial ecosystems and growth-oriented enterprises: background paper prepared for the workshop organised by the OECD LEED Programme and the Dutch Ministry of Economic Affairs.

Mata, J., Portugal, P., \& Guimaraes, P. (1995). The survival of new plants: start-up conditions and post-entry survival. International Journal of Industrial Organization, 13, 459-481.

Meoli, M., Paleari, S., \& Vismara, S. (2013). Completing the technology transfer process: M\&As of science-based IPOs. Small Business Economics, 40(2), 227-248.

Mercer, C. (2018). Which companies are making driverless cars? Techworld, Jan. 8, http://www.Techworld.com.

Moore, G., \& Davis, K. (2001). Learning the Silicon Valley way. Working Paper No. 00-45. Stanford: Stanford Institute for Economic Policy Research.

Nelson, R. (Ed.). (1993). National Innovation Systems: a comparative study. Oxford: Oxford University Press.

Norbäck, P. J., \& Persson, L. (2004). Privatization and foreign competition. Journal of International Economics, 62(2), 409-416.

North, D. C. (1990). Institutions, institutional change, and economic performance. Cambridge, UK: Cambridge University Press.

Qian, H., Acs, Z. J., and Stough, R. R. (2012). Regional systems of entrepreneurship: the nexus of human capital, knowledge and new firm formation. Journal of Economic Geography, lbs009.

Radosevic, S., \& Yoruk, E. (2013). Entrepreneurial propensity of innovation systems: theory, methodology and evidence. Research Policy, 42(5), 1015-1038.

Romer, P. (1986). Increasing returns and economic growth. American Economic Review, 94, 1002-1037.

Romer, P. (1990). Endogenous technical change. Journal of Political Economy, 98, 71-102.

SCB (2014). FoU-utgifter och FoU-årsverken i företags-sektorn, universitets- och högskolesektorn, samt offentlig sektor år 2013 (R\&D expenditures and R\&D man-years in business, universities, and the public sector, 2013), rapport 2014-0911, Stockholm: Statistiska Centralbyrån.

Scherer, F. M., \& Harhoff, D. (2000). Technology policy for a world of skew-distributed outcomes. Research Policy, 29(4 5), 559-566. 
Schumpeter, J. (1934). Theory of economic development. Cambridge, MA: Harvard University Press.

Schumpeter, J. A. (1942). Capitalism, socialism and democracy. New York: Harper and Row.

Shane, S. (2000). Prior knowledge and the discovery of entrepreneurial opportunities. Organization Science, 11(4), 448-469.

Shane, S. (2003). A general theory of entrepreneurship. The individual-opportunity Nexus. Cheltenham: Edward Elgar.

Shane, S., \& Venkataraman, S. (2000). The promise of entrepreneurship as a field of research. Academy of Management Review, 26(1), 217-226.

Stam, E. (2015). Entrepreneurial Ecosystems and Regional Policy: A Sympathetic Critique. European Planning Studies, 23(9), 1759-1769.

Stam, E., \& Spiegel, B. (2016). Entrepreneurial ecosystems and regional policy. SAGE Handbook for entrepreneurship and small business. Thousand Oaks: SAGE Publications.

Stankiewicz, R. (2002). The cognitive dynamics of biotechnology and the evolution of its technological system. In B. Carlsson (Ed.), Technological systems in the bio Iindustries: an international study (pp. 35-52). Boston: Kluwer Academic Publishers.

Stern, Scott (2005) Economic experiments: the role of entrepreneurship in economic prosperity. In Carl J. Schramm (Ed.), Understanding Entrepreneurship: A Research and Policy Report, Ewing Marion Kauffman Foundation, 16-20.
Stigler, G. J. (1950). Monopoly and oligopoly by merger. The American Economic Review, 40(2), 23-34.

Thompson, P., \& Chen, J. (2011) Disagreements, employee spinoffs and the choice of technology. Review of Economic Dynamics, 14(3) 455-474.

Utterback, J. M. (1996). Mastering the dynamics of innovation. Harvard Business Press.

Utterback, J. M., Meyer, M., Roberts, E., \& Reitberger, G. (1988). Technology and industrial innovation in Sweden: a study of technology-based firms formed between 1965 and 1980 . Research Policy, 17(1), 15-26.

Van de Ven, A. H. (1993). The development of an infrastructure for entrepreneurship. Journal of Business Venturing, 8, 211-230.

Wennberg, K., Wiklund, J., \& Wright, M. (2011). The effectiveness of university knowledge spillovers: performance differences between university spinoffs and corporate spinoffs. Research Policy, 40(8), 1128-1143.

Westlund, H., Larsson, J. P., \& Olsson, A. R. (2014). Start-ups and local entrepreneurial social capital in the municipalities of Sweden. Regional Studies, 48(6), 974-994.

Williamson, O. E. (1975). Markets and hierarchies. New York, 26-30.

Zahra, S., Van de Velde, E., \& Larraneta, B. (2007). Knowledge conversion capability and the growth of corporate and university spinoffs. Industrial and Corporate Change, 16(4), 569-608. 